J. Amer. Soc. Hort. Sci. 116(2):327-329. 1991

\title{
Relationship between Malate Dehydrogenase Isozyme Genotype and Plant Vigor in Peach
}

\author{
Dennis J. Werner and Dana F. Moxley \\ Department of Horticultural Science, Box 7609, North Carolina State University, Raleigh, \\ NC 27695-7609 \\ Additional index words. electrophoresis, isozyme
}

\begin{abstract}
The relationship between malate dehydrogenase (MDH) isozyme genotype and plant vigor in peach [Prunus persica (L.) Batsch] was examined in two $F_{2}$ populations (selfed 'Belle of Georgia' and 'Cresthaven') segregating at the Mdh1 locus. Total progeny examined were 1610 and 998 in the 'Belle of Georgia' and 'Cresthaven' populations, respectively. In both populations, plant vigor (as defined by total height and trunk caliper after 1 year of growth) was significantly less in Mdh1-1/Mdh1-1 homozygotes. Homozygous Mdh1-2/Mdh1-2 individuals showed the greatest vigor, and were significantly different in vigor from Mdh1-1/Mdh1-1 homozygotes in both populations and from Mdh11/Mdh1-2 heterozygotes in the 'Belle of Georgia' population. A significant deviation from the expected 1 Mdh1-1/ Mdh1-1 : 2 Mdh1-1/Mdh1-1 : 1 Mdh1-2/Mdh1-2 ratio was observed in the 'Belle of Georgia' population, suggesting moderate lethality of homozygous Mdh1-1/Mdh1-1 genotypes.
\end{abstract}

Isozyme polymorphism at the Mdhl locus in peach has been described by various authors. Arulsekar et al. (1986) and Durham et al. (1987) demonstrated that the variability observed for $\mathrm{MDH}$ in peach could be explained by the presence of two alleles ( $\mathrm{S}$ and F) interacting at a single locus, designated Mghl. Mowrey et al. (1990) reported the presence of a third allele (MdhI3 ) at the $M d h 1$ locus, and proposed the designation of Mdhl-1 and Mdh1-2 for the $\mathrm{F}$ and $\mathrm{S}$ alleles, respectively. Characterization of peach cultivars, breeding lines, and plant introductions for MDH has shown that Mdh1-1/Mdh1-1 homozygotes are very rare. Of 290 cultivars tested by Arulsekar et al, (1986), only six were Mdh1-1/Mdh1-1. Durham et al. (1987) found only one Mdh1-1lMdh1-1 homozygote among 59 cultivars and breeding lines surveyed. Mowrey et al. (1990) found only one Mdh1-1/ Mdh1-1 homozygote among 56 peach plant introductions. This is noteworthy, because the cultivar 'Chinese Cling', introduced into the United States in 1850 (Scorza et al., 1985), is homozygous Mdh1-1/Mdh1-1 (Arulsekar et al., 1986). This cultivar served as the base for cultivar improvement in most state and federal peach breeding programs. Most commercial peach cultivars grown today in the eastern United States can be traced back to 'Chinese Cling' (Scorza et al., 1985). Thus, the Mdh11 allele has been rapidly eliminated from breeding populations. Arulsekar et al. (1986) and Mowrey et al. (1990) have suggested that the Mdh1-1 allele in the homozygous state may have some selective disadvantage, or is closely linked to an undesirable character.

During routine electrophoretic analysis of various $F_{2}$ populations in support of our gene linkage studies in peach, an apparent association between MDH isozyme genotype and plant vigor was observed. This study was initiated to determine the relationship between $\mathrm{MDH}$ isozyme genotype and plant vigor in peach using two $\mathrm{F}_{2}$ populations segregating at the Mdhl locus.

Received for publication 25 May 1990. Research supported from funds provided by the N.C. Agricultural Research Service, Raleigh, NC 27695-7643. We thank Steve Worthington for technical assistance provided. Thanks to Jose Chaparro and Bruce Mowrey for discussions with the senior author that contributed to the initiation of this study. The cost of publishing this paper was defrayed in part by the payment of page charges. Under postal regulations, this paper therefore must be hereby marked advertisement solely to indicate this fact.

\section{Materials and Methods}

Two $\mathrm{F}_{2}$ populations (selfed 'Belle of Georgia' and 'Cresthaven') segregating for the $M d h 1-1$ and $M d h 1-2$ alleles at the $M d h 1$ locus were used to examine the relationship between MDH isozyme genotype and plant vigor. Seed from selfed plants was obtained from each cultivar in 1988 by enclosing trees in screen cages during bloom to exclude pollinating insects. Fruit were harvested when mature, and pits were removed from the fruit. Pits containing the seed were planted directly in the field in Oct. 1988 in methyl bromide-fumigated soil at the Sandhills Research Station, Jackson Springs, N.C. Seeds were spaced $\approx 10$ $\mathrm{cm}$ apart in rows $6 \mathrm{~m}$ apart. Seeds germinated in Mar. 1989 after exposure to natural stratification. Actively growing plants in both populations were characterized for MDH on morpholinecitrate ( $\mathrm{pH}$ 6.1) starch gels using standard electrophoretic techniques described by Mowrey et al. (1990). Plant vigor was determined by measuring total height and trunk caliper of each plant at the end of the first growing season. Total progeny examined were 1610 and 998 in the 'Belle of Georgia' and 'Cresthaven' populations, respectively. Mean plant height and caliper were calculated for each MDH isozyme genotype class within each population, and means were compared using the WallerDuncan K-ratio $t$ test (Wailer and Duncan, 1969).

\section{Results and Discussion}

Plant height and caliper were strongly correlated; only the plant height data are presented. Mean height of $\mathrm{F}_{2}$ trees from 'Belle of Georgia' $(135.0 \mathrm{~cm})$ was significantly greater than that from 'Cresthaven' $(121.6 \mathrm{~cm})$. In both populations, mean plant height was significantly less in $M d h 1-1 / M d h 1-1$ homozygotes when compared to the other genotypes (Table 1).

Table 1. Mean plant height of three malate dehydrogenase isozyme genotype groups in two $F_{2}$ peach populations after 1 year of growth.

\begin{tabular}{lcc}
\hline & \multicolumn{2}{c}{ Plant ht $(\mathrm{cm})$} \\
\cline { 2 - 3 } MDH genotype & \multicolumn{2}{c}{$\mathrm{F}_{2}$ population } \\
\hline Mdh1-1/Mdh1-1 & $108.3 \mathrm{a}$ & Cresthaven \\
Mdh1-1/Mdh1-2 & $139.4 \mathrm{~b}$ & $110.0 \mathrm{a}$ \\
Mdh1-2/Mdh1-2 & $148.1 \mathrm{c}$ & $125.5 \mathrm{~b}$ \\
\end{tabular}

${ }^{z}$ Mean separation within column by Waller-Duncan K-ratio $t$ test, (K $=100)$. 
Homozygous Mdh1-2/Mdh1-2 individuals showed the greatest vigor and were significantly different from $M d h 1-1 / M d h 1-1$ homozygotes in both populations and from $M d h 1-1 / M d h 1-2$ heterozygotes in the 'Belle of Georgia' population. The association between $\mathrm{MDH}$ genotype and plant vigor was greater in the 'Belle of Georgia' population than in 'Cresthaven', as shown by the frequency distribution data (Figs. 1 and 2). The additive effect [calculated as: (Mdh1-2/Mdh1-2 mean height - Mdh1-1/Mdh11 mean height)/2] associated with the Mdh1-2 allele was 19.9 and $7.8 \mathrm{~cm}$ in the 'Belle of Georgia' and 'Cresthaven' populations, respectively. Mean height of $M d h 1-1 / M d h 1-1$ homozygotes was $27 \%$ and $12 \%$ less than that of $M d h 1-2 / M d h 1-2$ homozygotes in the 'Belle of Georgia' and 'Cresthaven' populations, respectively (Table 1). A significant deviation from the expected 1 Mdh1-1lMdh1-1 : 2 Mdh1-1/Mdh1-2 : 1 Mdh1-2/ Mdh1-2 ratio was observed in the 'Belle of Georgia' population $\left(\chi^{2}=10.6, P<0.01\right)$, but not in the 'Cresthaven' population $\left(\chi^{2}=2.08, P=0.25-0.50\right)$ (Table 2). This result suggests that moderate lethality of $M d h 1-1 / M d h 1-1$ homozygotes may

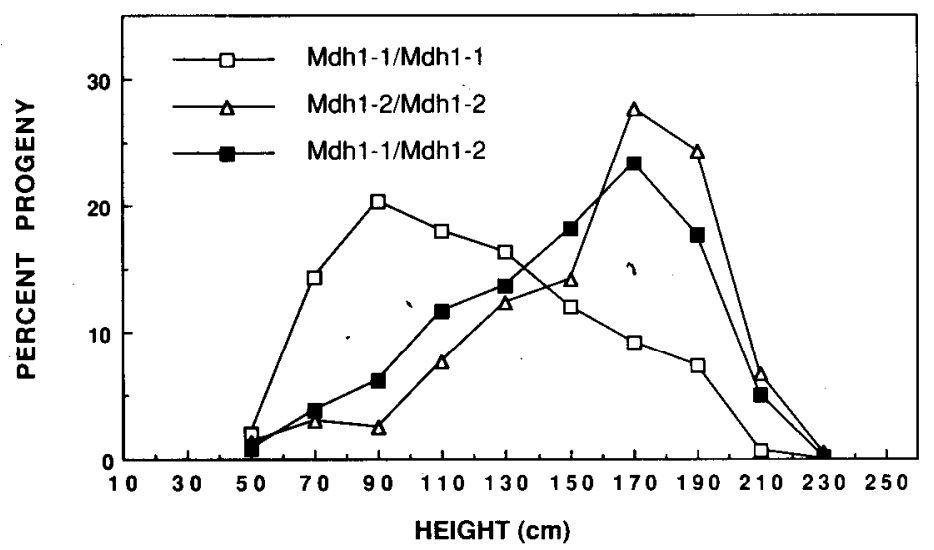

Fig. 1. Frequency distribution of three malate dehydrogenase isozyme classes (Mdh1-1/Mdh1-1, Mdh1-2/Mdh1-2, and Mdh1-1/Mdh12) in an $F_{2}$ population of 'Belle of Georgia' peach. Data points represent the percentage of total progeny within $\mathrm{MDH}$ class contained in the height interval defined by that $\mathrm{x}$ axis height value and the prior labeled value.

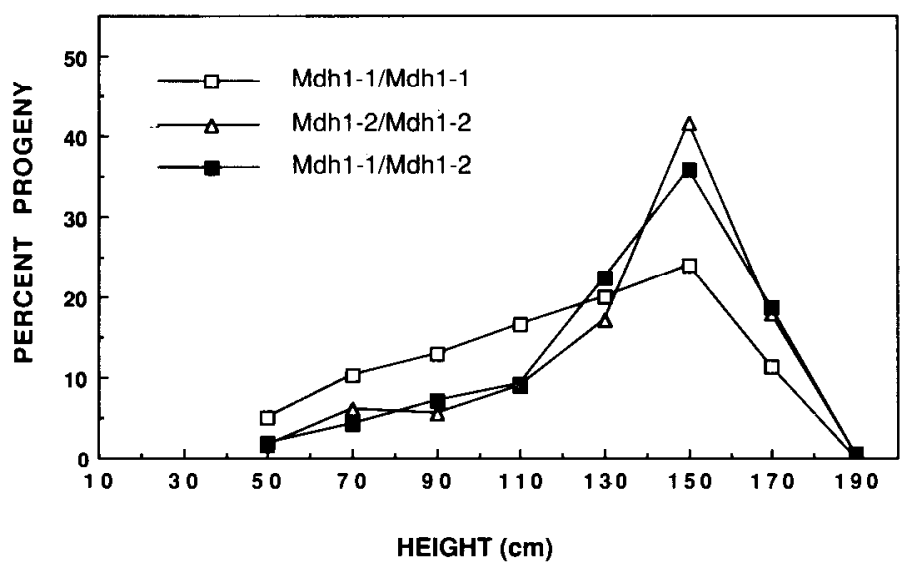

Fig. 2. Frequency distribution of three malate dehydrogenase isozyme classes (Mdh1-1/Mdh1-1, Mdh1-2/Mdh1-2, and Mdh1-1/Mdh12) in an $\mathrm{F}_{2}$ population of 'Cresthaven' peach. Data points represent the percentage of total progeny within MDH class contained in the height interval defined by that $\mathrm{x}$ axis height value and the prior labeled value.
Table 2. Phenotypic ratios and goodness-of-fit for segregation at the $M d h I$ isozyme locus in two peach $\mathrm{F}_{2}$ populations.

\begin{tabular}{|c|c|c|c|c|c|c|}
\hline \multirow[b]{2}{*}{$\mathrm{F}_{2}$ population } & \multicolumn{3}{|c|}{ Segregation classes } & \multirow[b]{2}{*}{$\begin{array}{l}\text { Test } \\
\text { ratio }\end{array}$} & \multirow[b]{2}{*}{$x^{2}$} & \multirow[b]{2}{*}{$P$ value } \\
\hline & $\begin{array}{c}M d h \\
1-1 / 1-1 \\
\end{array}$ & $\begin{array}{c}M d h \\
1-1 / 1-2\end{array}$ & $\begin{array}{c}M d h \\
1-2 / 1-2\end{array}$ & & & \\
\hline Belle of Georgia & 350 & 820 & 440 & $1: 2: 1$ & 10.6 & $<0.01$ \\
\hline Cresthaven & 246 & 483 & 269 & $1: 2: 1$ & 2.1 & $0.25-0.50$ \\
\hline
\end{tabular}

occur in certain genetic backgrounds and may explain partially the rarity of this genotype.

It is noteworthy that other homozygous $M d h 1-1 / M d h 1-1$ peach cultivars exhibit low vigor. 'Chinese Cling' and 'Siberian-C', both Mdh1-1/Mdh1-1 (Arulsekar et al., 1986), are low to modcrate in vigor (characterization of 'Siberian C' by R.E.C. Layne, personal communication). As early as 1932, Blake (1932) characterized the cultivar J.H. Hale (Mdh1-1/Mdh1-2) as "slightly dwarf" in habit. Blake (1933) further reported that 'Elberta' (heterozygous $M d h 1-1 / M d h 1-2$ ), a seedling of 'Chinese Cling' (Hedrick, 1917), produced numerous "semi-dwarf" and "full dwarf" seedlings. These reports further support the relationship between the homozygous $M d h 1-1 / M d h 1-1$ genotype and low vigor in peach.

Our results clearly show that $M d h 1-1 / M d h 1-1$ homozygotes are low in vigor, and that the relationship was greater in the 'Belle of Georgia' population as compared to 'Cresthaven'. 'Belle of Georgia' is a direct descendent of 'Chinese Cling', having originated as an open-pollinated seedling from it (Hedrick, 1917). Conversely, 'Cresthaven' has a more complex pedigree (Brooks and Olmo, 1972), and is about four generations removed from 'Chinese Cling'. Differences in the two populations regarding the relative effect of the $M d h 1-1$ allele on plant vigor may be attributed to differences in genetic backgrounds. It is possible that other genes affecting vigor, either in unlinked regions of the genome or in the region near the $M d h 1$ locus, also are segregating in the $\mathrm{F}_{2}$ population of 'Cresthaven', thus obscuring the relationship between vigor and $\mathrm{MDH}$ genotype.

We propose that one explanation for the rarity of homozygous Mdh1-1/Mdh1-1 genotypes among commercial peach cultivars and breeding lines is due to the marked reduction in vigor of these individuals, and their subsequent loss through natural competition in seedling rows and through culling by breeders during selection. Moderate lethality of Mdh1-1/Mdh1-1 homozygotes further reduces their numbers in breeding populations. Peach breeders have long lamented the production problems faced due to the undesirably high vigor of most commercial peach cultivars, and the lack of appropriate dwarfing rootstock and appropriate dwarf and semi-dwarf scion cultivars to address this concern. This study suggests that a full range in plant vigor can be obtained in young seedling populations segregating at the $M d h 1$ locus, and that this association between vigor and MDH genotype provides a convenient marker that can be characterized as early as the seed stage, if desired.

The basis for the relationship between MDH genotype and plant vigor cannot be determined from these data. Low vigor of $M d h 1-1 / M d h 1-1$ homozygotes could be due directly to the kinetics and cellular function of the actual variant isozyme itself. Alternatively, the Mdh1 locus may be closely linked to a gene with a major influence on plant vigor, and this gene may have been introduced with the MdhI-1 allele into current commercial germplasm from 'Chinese Cling'. The existence of some Mdh11/Mdh1-1 homozygotes exhibiting normal vigor in the two populations examined in this study lends support to the gene linkage 
hypothesis. Also, the presence of $M d h 1-2 / M d h 1-2$ homozygotes showing low vigor supports this hypothesis, in that such individuals may represent recombinant. These alternatives warrant further investigation.

\section{Literature Cited}

Arulsekar, S., D.E. Parfitt, W. Beres, and P.E. Hansche. 1986. Genetics of malate dehydrogenase in peach. J. Hered. 77:49-51.

Blake, M.A. 1932. The J.H. Hale peach as a parent in peach crosses. Proc. Amer. Soc. Hort. Sci. 29:131-136.

Blake, M.A. 1933. Elberta and its selfed and chance seedlings lack hardiness. N.J. Agr. Expt. Sta. Circ. 287.

Brooks, R.M. and H.P. Olmo. 1972. Register of new fruit and nut varieties. 2nd ed. Univ. of California Press, Berkeley.
Durham, R.E., G.A. Moore, and W.B. Sherman. 1987. Isozyme banding patterns and their usefulness as genetic markers in peach. J. Amer. Soc. Hort. Sci. 112:1013-1018.

Hedrick, U.P. 1917. The peaches of New York. Rpt. N.Y. Agr. Expt. Sta. 1916.

Mowrey, B.D., D.J. Werner, and D.F. Byrne. 1990. Inheritance of isocitrate dehydrogenase, malate dehydrogenase, and shikimate dehydrogenase in peach and peach $\mathrm{x}$ almond hybrids. J. Amer. Soc. Hort Sci. 115:312-319.

Scorza, R., S.A. Mehlenbacher, and G.W. Lightner. 1985. Inbreeding and coancestry of freestone peach cultivars of the eastern United States and implications for peach germplasm improvement. J. Amer. Soc. Hort. Sci. 110:547-552.

Waller, R.A. and D.B. Duncan. 1969. A Bayes rule for the symmetric multiple comparison problem. J. Amer. Stat. Assoc. 64:1487-1503. 